\title{
PENERAPAN REWARD AND PUNISHMENT UPAYA MENINGKATKAN DISIPLIN GURU DALAM KEHADIRAN MENGAJAR DIKELAS DI SDN 06 DEDAI KABUPATEN SINTANG
}

\author{
Buang \\ SDN 06 Dedai, Dinas Pendidikan Kabupaten Sintang \\ Email: Kepsekbuang.SPd.I@gmail.com
}

\begin{abstract}
Improving the quality of learning at school is very dependent on several factors. A very important factor is the application of culture towards improving quality. School culture is a positive thing that must be approved and implemented by all approved school members. One of the culture of schools that must be resolved is the problem of discipline, including the discipline of the teachers in class meetings in the teaching and learning process. To improve the discipline of teachers can be pursued in various ways. In this School Action Research (PTS), an attempt was made in the form of the application of Prizes and Punishment for teachers in SDN 06, Dedai District, Sintang Regency. This research was conducted in two cycles, because from the results of research and data analysis, shown in the second cycle, the discipline of teachers in class meetings in the teaching and learning process increased and met the indicators set by $75 \%$. From the results of this study, it can be concluded that to improve teacher discipline in class meetings in teaching and learning activities can be done by applying gifts and punishments to teachers.
\end{abstract}

Keywords: Teacher Discipline, Reward and Punishment. 


\begin{abstract}
Abstrak
Peningkatan mutu pembelajaran disekolah sangat tergantung dari beberapa faktor. Faktor yang sangat penting antara lain adalah penerapan budaya sekolah kearah peningkatan mutu. Budaya sekolah merupakan hal yang positif yang harus dipertahankan dan dilaksanakan oleh semua warga sekolah tanpa merasa terpaksa. Budaya sekolah yang harus dipertahankan salah satunya adalah masalah kedisiplinan, termasuk disiplin para guru dalam kehadiran dikelas pada proses belajar mengajar. Untuk meningkatkan disiplin para guru dapat diupayakan melalui bermacam-macam cara. Dalam Penelitian Tindakan Sekolah (PTS) ini, dicobakan tindakan berupa penerapan Reward and Punishment untuk para guru di SDN 06 Kecamatan Dedai Kabupaten Sintang. Penelitian ini dilaksanakan dalam dua siklus, karena dari hasil penelitian dan analisa data, ternyata pada siklus kedua, kedisiplinan guru dalam kehadiran dikelas pada proses belajar mengajar meningkat dan memenuhi indikator yang telah ditetapkan sebesar 75\%. Dari hasil penelitian ini, dapat disimpulkan bahwa untuk meningkatkan disiplin guru dalam kehadiran dikelas pada kegiatan belajar mengajar dapat dilakukan dengan penerapan Reward and Punishment kepada guru.
\end{abstract}

Kata Kunci: Disiplin Guru, Reward and Punishment. 


\section{A. Pendahuluan}

Untuk meningkatkan peranan guru dalam proses belajar mengajar dan hasil belajar siswa, maka guru diharapkan mampu menciptakan lingkungan belajar yang efektif dan akan mampu mengelola kelas. Guru adalah pendidik profesional dengan tugas utama mendidik dan mengevaluasi peserta didik, pada pendidikan anak usia dini jalur pendidikan formal, pendidikan dasar dan pendidikan menengah. Sementara pegawai dunia pendidikan merupakan bagian dari tenaga kependidikan, yaitu anggota masyarakat yang mengabdikan diri dan diangkat untuk menunjang penyelenggaraan pendidikan. Dalam informasi tentang wawasan Wiyatamandala, kedisiplinan guru diartikan sebagai sikap mental yang mengandung kerelaan mematuhi semua ketentuan, peraturan dan norma yang berlaku dalam menunaikan tugas dan tangung jawab.

Dari pengertian diatas dapat disimpulkan, kedisiplinan guru dan pegawai adalah sikap penuh kerelaan dalam mematuhi semua aturan dan norma yang ada dalam menjalankan tugasnya sebagai bentuk tanggung jawabnya terhadap pendidikan anak didiknya. Karena bagaimana pun seorang guru atau tenaga kependidikan (pegawai), merupakan cermin bagi anak didiknya dalam sikap atau teladan, dan sikap disiplin guru dan tenaga kependidikan (pegawai) akan memberikan warna terhadap hasil pendidikan yang jauh lebih baik.

\section{Keberhasilan}

proses pembelajaran sangat bergantung pada beberapa faktor diantaranya adalah faktor guru. Guru sangat memegang peranan penting dalam keberhasilan proses pembelajaran. Guru yang mempunyai kompetensi yang baik tentunya akan sangat mendukung keberhasilan proses pembelajaran.

Peranan guru selain sebagai seorang pengajar, guru juga berperan sebagai seorang pendidik. Pendidik adalah seiap orang yang dengan sengaja mempengaruhi orang lain untuk mencapai tingkat kemanusiaan yang lebih tinggi (Sutari Imam Barnado, 1989:44). Sehinggga sebagai pendidik, seorang guru harus memiliki kesadaran atau merasa mempunyai tugas dan kewajiban 
untuk mendidik. Tugas mendidik adalah tugas yang amat mulia atas dasar "panggilan" yang teramat suci. Sebagai komponen sentral dalam sistem pendidikan, pendidik mempunyai peran utama dalam membangun fondamen-fondamen hari depan corak kemanusiaan. Corak kemanusiaan yang dibangun dalam rangka pembangunan nasional kita adalah "manusia Indonesia seutuhnya", yaitu manusia yang beriman dan bertaqwa kepada Tuhan Yang Maha Esa, percaya diri disiplin, bermoral dan bertanggung jawab. Untuk mewujudkan hal itu, keteladanan dari seorang guru sebagai pendidik sangat dibutuhkan.

Keteladanan guru dapat dilihat dari prilaku guru sehari-hari baik didalam sekolah maupun diluar sekolah. Selain keteladanan guru, kedisiplinan guru juga menjadi salah satu hal penting yang harus dimiliki oleh guru sebagai seorang pengajar dan pendidik.

Fakta dilapangan yang sering kita jumpai disekolah adalah kurang disiplinnya guru, terutama masalah disiplin guru masuk kedalam kelas pada saat kegiatan pembelajaran dikelas.
Berdasarkan uraian diatas, penulis tertarik untuk melakukan penelitian tindakan sekolah dengan judul : "Penerapan Reward And Punishment Upaya Meningkatkan Disiplin Guru Dalam Kehadiran Mengajar Dikelas Di Sdn 06 Kecamatan Dedai Kabupaten Sintang”.

\section{B. Metode}

Metode yang digunakan dalam penelitian ini adalah metode Penelitian Tindakan Sekolah (PTS). PTS merupakan suatu prosedur penelitian yang diadaptasi dari Penelitian Tindakan Kelas (PTK) (Panitia Pelaksana Pendidikan dan Latihan Profesi Guru Rayon 10 Jawa Barat, 2009 : 73). Penelitian tindakan sekolah merupakan "(1) penelitian partisipatoris yang menekankan pada tindakan dan refleksi berdasarkan pertimbangan rasional dan logis untuk melakukan perbaikan terhadap suatu kondisi nyata; memperdalam pemahaman terhadap tindakan yang dilakukan; dan (3) memperbaiki situasi dan kondisi sekolah / pembelajaran secara praktis" (Depdiknas, 2008 : 11-12). Secara singkat, PTS bertujuan untuk mencari pemecahan permasalahan nyata yang terjadi di sekolahsekolah, sekaligus mencari jawaban 
ilmiah bagaimana masalah-masalah tersebut bisa dipecahkan melalui suatu tindakan perbaikan.

Pendekatan yang digunakan dalam penelitian tindakan ini ialah pendekatan kualitatif. Artinya, penelitian ini dilakukan karena ditemukan permasalahan rendahnya tingkat kedisiplinan guru dalam kehadiran dikelas pada proses kegiatan belajar mengajar. Permasalahan ini ditindak lanjuti dengan cara menerapkan sebuah model pembinaan kepada guru berupa penerapan Reward dan Punishment yang dilakukan oleh kepala sekolah, kegiatan tersebut diamati kemudian dianalisis dan direfleksi. Hasil revisi kemudian diterapkan kembali pada siklussiklus berikutnya.

\section{Pembahasan dan Hasil}

\section{Siklus I.}

Siklus 1 terdiri atas beberapa tahap, yaitu : (1) Perencanaan, (2) Pelaksanaan, (3) Pengamatan dan Evaluasi, dan (4) Refleksi.

Perencanaan terdiri dari Merumusan masalah yang akan dicari solusinya, Merumusan tujuan penyelesaian masalah/tujuan menghadapi tantangan/tujuan melakukan inovasi/tindakan. Merumusan indikator keberhasilan penerapan Reward dan Punishment dalam meningkatkan disiplin guru dalam kehadiran dikelas pada proses belajar mengajar. Merumusan langkah-langkah kegiatan penyelesaian masalah / kegiatan menghadapi tantangan / kegiatan melakukan tindakan. Mengidentifikasi warga sekolah dan atau pihak-pihak terkait lainnya yang terlibat dalam penyelesaian masalah / menghadai tantangan / melakukan tindakan.

Mengidentifikasi metode pengumpulan data yang akan digunakan. Penyusunan instrumen pengamatan dan evaluasi. Mengidenifikasi fasilitas yang diperlukan. Pelaksanaan penelitian tindakan sekolah ini dilaksanakan melalui beberapa kegiatan yaitu Menyebarkan lembar pengamatan kepada setiap guru SDN 06 Kec. Dedai Kab. Sintang. Berkoordinasi dengan petugas piket yang setiap hari terdiri dari 2 orang petugas, yaitu dari guru yang tidak mempunyai jam mengajar pada hari itu dan satu orang dari tata usaha. 
Setelah selesai jam pelajaran, dilakukan rekapitulasi dari hasil pengamatan, baik dari guru piket, dari siswa maupun dari penulis. Kegiatan tersebut dilakukan terus setiap hari kepada setiap guru selama satu minggu (satu siklus).

Pengamatan dan evaluasi dilakukan oleh peneliti dengan menggunakan lembar observasi selama satu minggu (satu siklus), untuk semua guru yang berjumlah 9 orang. Selama pengamatan peneliti dibantu atau berkolaborasi dengan guru piket. Pengamatan oleh peneliti meliputi, Kehadiran guru dikelas, Tingkat keterlambatan guru masuk kelas, Waktu meninggalkan kelas setelah selesai pelajaran.

Refleksi Setelah selesai satu siklus maka diadakan refleksi mengenai kelemahan atau kekurangan dari pelaksanaan tindakan pada siklus pertama, Refleksi dilaksanakan bersama-sama kolaborator untuk menentukan tindakan perbaikan pada siklus berikutnya, Dari hasil refleksi dapat diambil suatu kesimpulan bahwa perlu penerapan Reward dan Punishment yang lebih tegas lagi dari pada siklus pertama.

\section{SIKLUS II.}

Siklus 2 terdiri atas beberapa tahap, sama seperti siklus 1 yaitu : (1) Perencanaan, (2) Pelaksanaan, (3) Pengamatan dan Evaluasi, dan (4) Refleksi.

Perencanaan dari hasil refleksi pada siklus pertama, peneliti merencanakan untuk melakukan tindakan Reward dan Punishment yang lebih tegas dibandingkan dengan siklus pertama.

$$
\text { Pelaksanaan penelitian }
$$
tindakan sekolah pada siklus yang kedua ini dilaksanakan melalui beberapa kegiatan, yaitu Menyebarkan lembar pengamatan kepada setiap guru SDN 06 Kec. Dedai Kab. Sintang, Berkoordinasi dengan petugas piket yang setiap hari terdiri dari 2 orang petugas, yaitu dari guru yang tidak mempunyai jam mengajar pada hari itu dan satu orang dari tata usaha. Setelah selesai jam pelajaran, dilakukan rekapitulasi dari hasil pengamatan, baik dari guru piket, dari siswa maupun dari penulis.

Pengamatan dan Evaluasi Pengamatan atau observasi dilakukan oleh peneliti dengan menggunakan lembar observasi selama satu minggu 
(satu siklus), untuk semua guru. Selama pengamatan peneliti dibantu atau berkolaborasi dengan guru piket. Pengamatan oleh peneliti meliputi Kehadiran guru dikelas, Tingkat keterlambatan guru masuk kelas, Waktu meninggalkan kelas setelah selesai pelajaran.

$$
\text { Reflesi Setelah selesai }
$$
pelaksanaan tindakan pada siklus kedua maka diadakan refleksi mengenai kelemahan atau kekurangan dari pelaksanaan tindakan pada siklus kedua tersebut Dari hasil observasi dan data yang diperoleh, peneliti mengambil kesimpulan bahwa tindakan yang dilaksanakan pada siklus kedua dinyatakan berhasil, karena terdapat $78,26 \%$ guru yang terlambat kurang dari 10 menit, atau melebihi target yang telah ditentukan sebesar $75 \%$.

\section{Simpulan}

Berdasarkan analisis data, dari penelitian ini dapat ditarik kesimpulan bahwa penerapan Reward dan Punishment efektif untuk meningkatkan disiplin kehadiran guru dikelas pada kegiatan belajar mengajar.

Data yang diperoleh menunjukan bahwa setelah diadakan penerapan tindakan berupa Reward dan Punishment, guru yang terlambat lebih dari 15 menit adalah 0, dan guru yang terlambat kurang dari 10 menit sebanyak 7 orang guru. Penerapan Reward dan Punishment dapat meningkat disiplin guru hadir didalam kelas padakegiatan belajar mengajar di SDN 06 Kec. Dedai Kab. Sintang.

\section{Daftar Pustaka}

Akhmad Sudrajat, (2010) Manfaat Prinsip dan Asas Pengembangan Budaya Sekolah. Jakarta: Gahli Indonesia.

Amstrong. Michael, (1991). Manajemen Sumber Daya Manusia. Jakrta:Ghalia Indonesia.

Anwar Prabu Mangkunegara. (1994). Psikologi Perusahaan. Bandung:PT. Trigenda Karya

_ (2000). Manajemen Sumber Daya Manusia Perusahaan.

Arikunto, S. (2002). Prosedur Penelitian Suatu Pendekatan Praktek. Jakarta:Rineka Cipta

Aunurrahman. (2009). Belajar dan Pembelajaran.Bandung:Alfabeta

Departemen Pendidikan

Nasional. (2003).

Undang-undang Nomor 20

Tahun 2003. 
Megawangi, Ratna. (2007).

Membangun SDM Indonesia

Melalui Pendidikan Holistik

Berbasis Karakter.

Jakarta:Indonesian Heritage Foundation

Asmaroini, Ambiro Puji. 2017. Menjaga Eksistensi Pancasila dan Penerapannya Bagi Masyarakat Di Era Globalisasi. Jurnal Pancasila dan Kewarganegaraan. 1 (2) : 53-59.

Subagio. (2010) Kompetensi Guru dalam Meningkatkan Mutu
Pembelajaran. Jakarta: Apitul langga.

Syamsul Hadi, (2009). Kepemimpinan Pembelajaran, Makalah Disampaikan padaSosialisasi Akuntabilitas Kinerja Kepala Sekolah Dalam Inovasi Pembelajaran. Departemen Pendidikan Nasional, Direktorat Jenderal Peningkatan Mutu Pendidik dan Tenaga Kependidikan, Direktorat Tenaga Kependidikan. 